\title{
Encounters in Educating English as a Second Language in India
}

\author{
A. G. Vadivelan, S. Rajkumar
}

\begin{abstract}
This paper looks at the present status of English as a second language in India. It characterizes language and distinguishes the variables that influence second language learning. It talks about various issues looked by students of English and what is the correct method for language securing for second language students in India. Language goes about as an instrument to express adequately in different informative circumstances. Be that as it may, it is an exact moment the language which involves a cognizant and constant, precise endeavors to gain or use this. The second language obtaining is extremely a major test for every single local speaker of that language who truly manage it. Most of Indian understudies, especially from rustic pockets think about this type of sevenletter word as a supernatural and mysterious word. A sentiment of awkwardness sets in, the minute pupils overhear something in English. Accordingly, instructors who handle English classes face outlandish troubles. Understudies think that its hard to tune in and to comprehend the language in English. What are the determinations behind this? And What is the medicinal measures to be taken to reduce these issues? This research paper is an endeavor to examine the idea of the second language procurement and the components in charge of its moderate obtaining, particularly in the provincial pockets of India. Fitting and satisfactory healing measures are referred to for the fruitful correction of these issues.
\end{abstract}

Keywords: Second Language, Correct Method, Supernatural, Understudies, Determinations.

\section{INTRODUCTION}

\section{$T$} he investigation of language is the establishment of all other learning. Language characterizes us as human. To be human is to utilize the language, and to talk is to be an individual one. The Language is the mechanism of all correspondence. English as a groundbreaking vehicle of correspondence fills in as a connection language in a multiethnic and bilingual civilization like India and furthermore as a worldwide semantic middle person. Throughout the years, this language has risen as an prominent language of decision to trade, financial development and social portability. Training understudies English has reliably developed as one of the top desires for guardians from school.

Revised Manuscript Received on December 24, 2019

* Correspondence Author

Dr. A.G. Vadivelan., English department, Kalasalingam Academy of Research and Education, Krishnankoil, Tamil Nadu, India. vadivelanag@gmail.com

Mr. S. Rajkumar, English department, Kalasalingam Academy of Research and Education, Krishnankoil, Tamil Nadu, India. Pandiarajammal.p@klu.ac.in

\section{ENCOUNTERS: EDUCATING AS A SECONDLANGUAGE}

In India, classes of blended capacity gatherings are a component of each community or township. In the majority of the provincial pieces of India, getting the hang of encouraging procedure is prepared in the lingo language. Then again, the majority of the aggressive analyses (advanced tutoring and work) entail English as vehicle of guidance. The fraction of understudies to instructors is extraordinary, prompting ineffectualness. The pastoral air does not give understudies the fortuitous to chat and learn English. The measure of the classes wherever is significantly enormous. This is one reason why distinct consideration is beyond the dominion of imagination to the understudies. Educating of English needs an intense change to serve students in schools and universities.

When contrasted with the students from metropolitan territories, students from the rustic regions aspect more challenge amid the system of language acquiring. In inner-city zones guardians are for the most part taught. Along these lines, the local condition enables the understudies from urban zones to get the language rapidly. Understudies don't get the opportunity to talk or peruse in English in the provincial pieces of the nation. In towns and communities understudies primarily hail from provincial territories. Bilingual technique is embraced in language classes. This technique causes just to ease back students somewhat. In addition, this demonstration diminishes the genuine learning process all in all. On the off chance that an understudy does not comprehend in English, the individual in question requests a clarification in L1 for example in the first language. Therefore, the English tutor is in a state to receive bilingual technique.

Absence of prime instructors in country regions has crooked into a reality. Educating is a ceaseless procedure and educators in rustic India are frequently suspended for going to attend workshops and courses to acquaint themselves with innovative means and approaches. "All through India, there is a conviction among practically all positions and classes in both rustic and urban zones in the transformative intensity of English. English is seen as a helpful expertise as well as an image of a better life, a pathway out of neediness and abuse". (Graddol p.12)

The punctuation interpretation technique is utilized by the instructor to show youthful kids, where the educator discloses all words to understudies in the local dialectal to mark him/her grasp and learn the language. Nonetheless, this strategy faces a noteworthy drawback. Mutually the tutor and the pupil focus extra on L1 as a replacement for of L2.

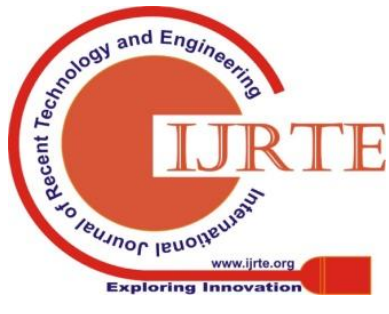


In this approach, Language class is by all accounts L1 classes as opposed to L2 class. Understudies get just restricted advantage through this methodology. Shockingly, this is still being used in numerous country schools all through India. The country, encompassing does not empower the student to rehearse any of the abilities. Numerous instructors are unfit to show English adequately on the grounds that they face a great deal of issues because of the absence of showing helps, non-accessibility of required specialized help and important environment to show English successfully.

Educator arrangement courses are not ready to outfit the instructors with sufficient learning, aptitudes and the capacity to have the option to show the concern subject successfully in the class. The context is aggravated by the way that This English isn't the language of exchange in rustic India, in this way, giving educators an almost no shot of rehearsing what they have realized. Instructors need to overhaul themselves through an assortment of methods - occasional workshops, video/sound chronicles of substance to be educated, undertakings and assignments.

Most of Indian rustic understudies determine English as an exceptionally troublesome subject to acquire. Because a large portion of the understudies is original students, they prerequisite the direction from guardians and others. Despite the fact that understudies contemplate English, they are not ready to create even a private sentence with no syntactic mistake in English. Our analysis framework is with the end goal that it makes understudies' repetition remembrance instead of testing their expository and innovative aptitudes. In this procedure, they retain exercises, replicate them in test lobbies and overlook them that daytime itself.

We cannot anticipate a constant standard of articulation for the second language in such a huge nation, where the native language is also pronounced distinctively by various gatherings of the general population having a place with a similar language network. In figuring out how to communicate in English, the primary language for the most part meddles with its elocution. The students just as the instructors communicate in English with local language propensities. Notwithstanding amid the English time frames most educators show the language without giving the understudies legitimate preparation in discourse since they are not appropriately sufficiently prepared to rehearse it. They overlook that each language contrasts in pressure, inflection and elocution. The outcome is that in the wake of learning/showing English for a long time at school and school, a great many people can't talk the language with clear exactness.

Listening is a significant language learning aptitude but then the most ignored expertise in Indian study halls. It is disregarded as educators assume that students naturally procure this ability with no uncommon preparing Companion educating, pretend and gathering exercises, are uncommon in Indian homerooms. In India, addresses talk. Instructor talking time is the greater part of the recommended time. The students are not urged to pose inquiries. The educators must include their understudies to work two by two, gatherings and groups and plan research projects, ventures, and so forth. Along these lines, despite being shown English in school and school for quite a while, students neglect to gain proficiency with the language. They are unable to write inadequate English by own and can't utilize properly.

\section{COUNTERACTIVE MEASURES}

Difficulties of English language tutors in India are colossal. It turns out to be all the more testing and requesting in rustic zones on the grounds that in such regions the instructor is the model, to whom an understudy searches for all adapting needs. They ought to have the option to oblige the down to earth needs of students, to make them sufficiently skillful to connect with each other and furthermore to recover data everywhere throughout the group. Spot of English ought to be characterized-English offers tremendous chances for all. The arrangement with respect to the spot of English in our instruction framework ought to be very much characterized. This ought to be resolved to keep in view its utilization and huge open doors in the pitch of science, innovation, sociologies, reasoning, news coverage, global exchange and tact.

\section{THE IMPORTANT REMEDIES HAVE TO BE FOLLOWED WHILE EDUCATING ENGLISH}

An educator's job is monstrous in country territories as the understudy has just an instructor to mimic and gain from. Educators' obligation lies not just with the normal or more normal understudies yet additionally with beneath normal and moderate students. A decent instructor needs to deal with classes for every one of the understudies in a homeroom. Singular consideration will take care of numerous issues, which emerge while enchanting classes. All the English instructors need to impulse the understudies to communicate in English. This demonstration makes them to secure some certain changes. Educators ought to persuade understudies for contributing in learning. It will explain all the hindrances in understudies. Instructing learning is definitely not a single direction process.

\section{CONCLUSION}

In our India, the larger part of the employees originates from country zones as lives in towns. All the arrangement producers need to connect the urban-rustic separation in educating of English. An English tutor instructing in provincial schools needs to concoct imaginative methodologies in the homerooms. Gifted and submitted instructors should be named at essential dimension. Educators ought to be redesigned and prepared to come across the issues of the students.

\section{REFERENCES}

1. Parel, M. ( 2008). English Language Teaching, (Methods, Tools and Techniques)

2. Graddol D. The future of English

3. Hanumanthrao, C.R. (2011) Teaching English Language: Problems and Remedies 
4. Prem Shankar (2003) Teaching of English, New Delhi, APH Publishing Corporation

\section{AUTHORS PROFILE}

Dr. A.G. Vadivelan, PhD., graduated at Anna University, Tamil Nadu, India, presented and published papers at National and International Conference. Published papers at International Journals. Guided UG, PG Projects and MPhil Dissertation.

Mr. S. Rajkumar, M.A., M.Phil., graduated at Madurai Kamaraj University, Tamil Nadu, India, presented and published papers at International Conference, won the best teacher award, guided UG projects, working as an Assistant Professor at Kalasalingam Academy of Research and Education, Tamil Nadu, India. 